\title{
Harmonization of Regulations Regarding Press Coverage Respect the Principle of Presumption of Innocence in the Press Law
}

\author{
Mustawa $^{1} \quad$ Judhariksawan $^{2} \quad$ Said Karim $^{2} \quad$ Maskun $^{3}$ \\ 1.Doctoral Student, Faculty of Law, Hasanuddin University, Indonesia \\ 2.Professor Of Law, Faculty of Law, Hasanuddin University, Indonesia \\ 3.Associate Professor Of Law, Faculty of Law, Hasanuddin University, Indonesia
}

\begin{abstract}
This journal aims to examine the need for harmonization of press reporting arrangements that respect the presumption of innocence and the competence of journalists to write legal news and standards for the journalist profession in the Press Law. This harmonization is intended so that one material with another material can complement each other to respect the presumption of innocence. The aim is to avoid a legal vacuum, because of things or circumstances that have not been regulated in the Press Law, or even if they have been regulated in a statutory regulation but are not clear or even incomplete. Legal vacancies eventually lead to legal uncertainty (rechtsonzekerheid), which will further create legal chaos (rechtsverwarring). This legal uncertainty, so journalists who write legal news are not supported by adequate legal knowledge, and journalist professional standards also use different recruitment criteria. As a result, it creates difficulties to create a responsible press.
\end{abstract}

Keywords: Harmonization, Regulation, The Press Respects The Principle Presumption Of Innocence.

DOI: $10.7176 / \mathrm{JLPG} / 91-10$

Publication date: November $30^{\text {th }} 2019$

\section{INTRODUCTION}

The regulation of news that respects the principle of presumption of innocence needs to be harmonized with journalists who have the competence to write legal news, and professional standards for journalists in the material provisions of the Press Law. Journalist competencies to write legal news and journalist professional standards are two variables that cannot be separated as a news system that has become the norm in the Press Law. The regulation of legal reporting without the competence of journalists to write legal news and professional standards for journalists will be difficult to implement press reports that respect the presumption of innocence, so that foothold material must be sought and explained in regulating the provisions of the Press Law.

Harmonization of the press coverage regulation is needed to maintain harmony, consistency, harmony, completeness, and integrity/ roundness of legislation as part of the legal system in order to function appropriately and effectively.

The researcher grouped 3 (three) arrangements for the press reporting system that regulates the press, ie reporting respects the presumption of innocence, the competence of journalists to write legal news and journalist professional standards whose contents need to be harmonized. The three settings are explained as follows:

\section{LITERATURE REVIEW}

1. Press News Respects the Principle of the Presumption of Innocence

The press in the news respects the presumption of innocence, where the press is obliged to report events and opinions by respecting religious norms and a sense of public morality and the principle of presumption of innocence. This is confirmed in the explanation of article 5 paragraph (1) of Law No. 40 of 1999 concerning the Press, as follows:

The national press in broadcasting information, does not judge or make conclusions about someone's mistakes, especially for cases that are still in the judicial process, and can accommodate the interests of all parties involved in the reporting.

Explanation of the aforementioned article, there are two elements of the news which become criminal acts if there is a violation in the Press Law, namely. First: The press does not judge or conclude someone's mistakes. Second, accommodate the interests of all parties involved in the news. The two elements are described as follows:

\section{a. The National Press is not Judging}

The provisions of the national press in broadcasting information, not judging or making conclusions about someone's mistakes, moreover cases that are still in the judicial process, and can accommodate the interests of all parties involved in the news. However, it does not mean that the press may not broadcast events of legal cases, the press may broadcast / present a legal fact or event starting from the police process, the prosecutor's office until the court stage based on the facts of events occurring in the field but may not make judgmental news. ${ }^{1}$

\footnotetext{
${ }^{1}$ Hendrayana, Upholding Press Freedom and the Implementation of the Presumption of Innocence Principle, Jurnal Dewan Pers, edition No. 2, November 2010, p. 84, accessed from https://dewanpers.or.id, on May 8, 2019.
} 
Errors in writing news in its application sometimes occur not because of something planned but the use of words with misperceptions regarding a person's legal status in the legal process. A person's legal status is seen as being equal to the status that occurs in a particular event. The emergence of certain words made by journalists in writing news such as, the perpetrators should be suspects, suspects should be witnesses, free should be released, charges rejected should not be accepted. In addition, there are also media using 'safety' with rumors, rumors, allegedly, said to be heard, rumored. The safeguards are meant to avoid acting non-judgmental opinions, if indeed the news is indeed incorrect. Conversely, if it is true, the press must risk the legal process. In fact, there is a media openly calling on someone's identity to be clearly involved in a criminal act, giving an impression to the reader that he is guilty before a court decision that has permanent legal force.

A person who is concerned with 'good name' or 'honor' is very important. It is important to avoid 'labeling' on the negative of the person concerned, or the image, credibility of an institution or body, both private and public. Attaching predicates, both textually and contextually, to individuals, legal entities, officials, public bodies or certain professions, which have negative connotations, including but not limited to 'juridical predicates' in inaccurate legal processes, can be viewed as ignoring the presumption of innocence. Judicial preaching and concluding someone's mistake before being declared so by the court, show that intentions on human rights imaging carried out by the press. ${ }^{1}$

\section{b. Accommodating the Interests of All Parties in Press Reporting}

Press coverage can be said to violate the principle of presumption of innocence if the content has indeed been judging someone or several people who have been involved or guilty of committing a crime, even though it has not been proven through a court decision that has permanent legal force. Avoiding these accusations, the press in news writing must be able to accommodate the interests of all parties in the news, according to the provisions in Article 5 paragraph (1) Press Law which is technically journalistic categorized as balanced news according to Article $3 \mathrm{~b}$ of the Journalistic Ethics Code. ${ }^{2}$

The principle of presumption of innocence stipulated in the Criminal Procedure Code and Press Law has different meanings. The Criminal Procedure Code still places the principle of presumption of innocence not as a norm, but in the Press Law it has been put in place as a norm or rule. On that basis, the Press Law explicitly gives the threat of criminal penalties to violators as stipulated in Article 18 paragraph (2) with a penalty of a maximum of Rp. 500,000,000.00 (five hundred million rupiah). ${ }^{3}$

Avoiding the threat of punishment in news writing, technically journalism which becomes a benchmark for journalists before broadcasting information is required to test information as emphasized in Article 3 of the Journalistic Code of Ethics. Testing information is intended to check and recheck the correctness of the information.

In order to fulfill the element of testing information, give attention to all journalists so that they are always careful to receive information. Every information received is not as well as a source of news, but it is checked and rechecked first to ensure the correctness of the information. Even after checking and rechecking in the field and proving the truth of the information, it was also not considered feasible to be reported because the elements of balance and non-opinion were not fulfilled in news writing.

To respect those involved in the legal process, before the decision of a judge who has definite legal force (inkracht van gewijsde) must be considered not guilty. Therefore the press must respect that right. In honor of the suspects because of this principle, the press took several attitudes. Some reported arrest, detention and prosecution before the court by writing abbreviated names or initials. Other publishers, using initial names or surnames when writing news of arrest, detention, but after entering the trial phase in court use their full names. Issuance of other press, there are also those who use full names from the process of arrest until the court process. For this matter there is indeed no uniformity.

Proclaiming the identity of criminal suspects today in terms of journalism is increasingly difficult to avoid. Technological advances have created electronic press such as television. In television reports the camera clearly captures the suspect's face and face, so the general can see it clearly. If the electronic press had broadcast the suspect's profile so clearly, but the print press was still hiding the identity of the suspect, of course the print press would be a laughing stock, because it kept something publicly known. From a commercial angle, the print press will experience osses, even though more and more rivals. Inevitably to satisfy their readers and make commercial profits, the print press also tends to reveal the identity of suspects as they are. ${ }^{4}$

Avoiding violations of the presumption of innocence in news writing, the press must understand the Press

\footnotetext{
${ }^{1}$ Chairul Huda, The Meaning of the Principles of Presumption Not Guilty and Their Use in Press Practices, Jurnal Dewan Pers, edition No. 2 , November 2010, page 38, accessed from https://dewanpers.or.id, on May 8, 2019.

${ }^{2}$ See the interpretation of Article 3 b Press Council Decree Number: 03/ SK-DP / III / 2006 concerning the Journalistic Code of Ethics, which means balanced is to provide space or time for reporting to each party proportionally.

${ }^{3}$ Article 18 paragraph (2) of Law Number 40 of 1999 concerning the Press that: Press companies that violate the provisions of Article 5 paragraph (1) and paragraph (2), as well as Article 13 are liable to a maximum fine of Rp. 500,000,000.00 (Five hundred million rupiah).

${ }^{4}$ Wina Armada, 1989, Face of Criminal Law Press. Jakarta: Pustaka Kartini, p. 75.
} 
Law, Journalistic Code of Ethics and become a 'pocket book' journalist. This is the basis of legal references and norms as well as professional ethics in carrying out journalistic duties.

\section{c. Journalists Competence to Write Legal News}

The regulation of press coverage that respects the principle of presumption of innocence in accordance with the provisions in Article 5 paragraph (1) of Law No. 40 of 1999, which is not accompanied by journalist competency standards as the author of legal news, the violation of the principle of presumption of innocence in press reports is difficult to avoid. ${ }^{1}$ For (written) laws or regulations to actually function effectively, ... the law or regulation itself (must be complete) must be synchronized with one another.

The regulation of journalists' competence in writing legal news has not found a basis for its regulation in the Press Law, so that there is disharmony with the regulation of the application of the presumption of innocence in press reports. As a result, violations of the principle of presumption of innocence in the press are still common, especially in the use of inappropriate legal terms. For journalists who come from non-legal educational backgrounds often report the facts instead assess the facts. Examples of perpetrators should be suspects, free sentences should be free, the investigation should be an investigation, expert witnesses should be expert testimony, and so on. Disharmoni law occurs because there is an inconsistency between one legal norm and the other legal norms, so harmonization is needed so that harmony occurs between one regulatory material and the other in one law.

According to Sidharta at the time of harmonizing, there could be several possibilities that caused disharmony in the legal system, namely: ${ }^{2}$

1) Vertical inconsistencies occur in terms of the format of regulations, namely regulations whose hierarchy is lower in opposition to the higher hierarchy of regulations, for example between government regulations and laws.

2) There is inconsistency vertically in terms of time, that is, some rules are hierarchically parallel but the one is first applicable than the other.

3) Inconsistencies occur horizontally in terms of the substance of regulation, namely some rules that are hierarchically parallel but the substance of one rule is more general than other regulatory substances.

4) Inconsistencies occur horizontally in terms of substance in the same regulation, for example the provisions of article 1 conflict with the provisions of article 15 of the same law.

5) Inconsistencies occur between the formal sources of different laws, for example between laws and judges' decisions or between laws and customs.

Sidharta's thinking in part (d), " there is horizontal inconsistency in terms of substance in the same regulation ... " according to the researcher, it happened in Law No. 40 of 1999 concerning the Press, because of the regulation of press coverage in Article 5 paragraph ( 1) not accompanied by regulation of journalist competencies so that the goal of respecting the presumption of innocence is still a frequent violation.

Article 15 paragraph (2) of Law No. 40 of $1999^{3}$ has mandated the Press Council to facilitate press organizations in drafting regulations in the field of the press and improving the quality of the profession of journalists. On this basis, the Press Council issued Regulation Number 01 / Regulation-DP / X / 2018 concerning Journalist Competency Standards, as follows:

\section{Awareness \\ 2. Knowledge \\ 3. Skills}

The journalist's competency standard stipulated in the Press Council Regulation, according to the researcher, is contrary to the provisions of article 5 paragraph (1) of the Press Law, as a manifestation of news that respects the presumption of innocence. The researcher analyzed two conflicting factors. These two factors are explained as follows: 4

\section{a) Factors of Journalist Knowledge}

The knowledge of journalists, especially those from legal disciplines, is an influential factor in providing correct legal information, especially in realizing the principle of presumption of innocence in press coverage in accordance with Article 5 paragraph (2) of the Press Law. Press Council regulations do not regulate that, but

\footnotetext{
${ }^{1}$ Ibid. p. 110.

${ }^{2}$ Slamet Hariyadi, 2012, Disharmoni of Legal Products, in Sidharta et al, Towards the harmonization of the legal system as the Pillar of Management of the Indonesian Coastal Areas, Jakarta: Bapenas, accessed from https://www.academia.edu, on 15 May 2019.

${ }^{3}$ See Article 15 paragraph (2) of Law No. 40 of 1999, that: The Press Council carries out the following functions: a. protect the freedom of the press from interference from other parties, b. conduct studies for the development of press life, c. Establish and supervise the implementation of journalistic code of ethics, d. give consideration and seek resolution of public complaints on cases related to press reporting, e.develop communication between the press, the public and the government, f. facilitate press organizations in developing regulations in the field of press and improve the quality of the journalism profession, $g$. list of press companies.

${ }^{4}$ See Appendix to Press Council Regulation No. 01 / Regulation-DP / X / 2018, p. 9-12.
} 
arrangements are applied to journalists in general or from various disciplines. Legal news should be written by journalists with legal education background so that there is a harmonization with press reports that respect the presumption of innocence.

\section{b) Legal Factors}

The Press Law is binding because the nature of the establishment of the Law is a legal product by regulating criminal acts for violators. The Press Council Regulation is not binding because of the nature of the regulation not a legal product, as stipulated in Law Number 12 of 2011 concerning the Establishment of Legislation. ${ }^{1}$ The regulation of journalist competencies should be part of the article regulating press coverage into the Law so that it is binding for the realization of law enforcement against the Press Law.

To facilitate harmonization, the foundation is laid out which includes various elements or units of competence, good legal knowledge, news writing skills that enable it to carry out coverage by referring to the standards of legal news writing stipulated in Article 3 paragraph (1) Journalistic Code of Ethics. These two arrangements are conditions that cannot be eliminated for the sake of the realization of press reports that respect the presumption of innocence.

The purpose of this competency setting is to improve the quality and professionalism of journalists, maintain the dignity of the journalism profession as a special profession producing intellectual work, becoming a reference for journalists' performance evaluation systems by press companies, placing journalists in strategic positions in the press industry, avoiding misuse of the journalist profession. and enforce press freedom based on public interest. $^{2}$

\section{c) Professional Standards for Journalists}

In carrying out journalistic activities, journalists have a professional standard so that in carrying out their work they can act professionally in accordance with the journalistic code of ethics. A professional journalist in press publishing has the qualifications to recruit journalists. Qualifications that become the standard of the journalist profession are as follows: ${ }^{3}$

a. Mastering Journalistic skills

b. Mastering the Field of Coverage

c. Adhere to the journalistic ethics code

The qualification of journalists' knowledge and the field of task coverage according to the author is one of the factors that determine the accuracy of the news. The more knowledgeable the journalists are in the field of coverage, the more they can provide correct information and the writing of journalists is more trusted by their readers. Conversely, the less knowledge a journalist has in the field of coverage, the less information can be provided, and by itself the journalist's writing is less trusted.

Journalist profession is a noble job, because they work for the benefit of the wider community in general. If the work will be used properly and without violating journalistic rules, then a journalist will get full trust from the community or readers, viewers. News that is very diverse, both in the fields of education, culture, law, politics, social, economy and so on, is certainly a challenge for journalists in carrying out their duties in the field.

Not regulating journalist professional standards into the Press Law is different from other professions, such as advocates and notaries, even though journalists are also professions that have expertise, associations and codes of ethics, have infringement rights and refusal rights to mention sources if it endangers the safety of the resource person. The press calls the work of journalists as people who regularly carry out journalistic activities. While Article 1 paragraph (1) of Law Number 40 of 1999 explains that:

The press is a social institution and a vehicle for mass communication that carries out journalistic activities including seeking, obtaining, possessing, storing, processing and displaying information in the form of writing, voice, images, sounds and images as well as data and graphics and other forms using print media. electronic media and all types of channels available. ${ }^{4}$

In general there are several characteristics or traits that are always inherent in the profession, namely as follows: ${ }^{5}$

a) There is special knowledge, which is usually possessed of expertise and skills thanks to years of

\footnotetext{
${ }^{1}$ See Article 7 paragraph (1) of Law Number 12 of 2011 concerning Formation of Regulations of Laws consisting of: a. The 1945 Constitution of the Republic of Indonesia; b. Decree of the People's Consultative Assembly; c. Government Regulations / Regulations Substituting Laws; d. Government Regulations; e. Presidential Regulations; f. Provincial Regional Regulations; and g. Regency / City Regulations.

${ }^{2}$ See Appendix to Press Council Regulation No. 01 / Regulation-DP / X / 2018, p.6.

${ }^{3}$ Romeltea, Standar Profesi Wartawan, diakses dari https://romeltea.com/, pada tanggal 20 Mei 2019

${ }^{4}$ Jealson, the Responsibility of Professional Journalists in the News, was accessed from https://steemit.com/jurnalis/@jealson, on May 20, 2019 ,

${ }^{5}$ See Article 2 of Law No. 18 of 2003, the provisions for the appointment of Advocates as follows: 1. Those who can be appointed as Advocates are graduates with a legal higher education background and after following the special education of the Advocate profession carried out by the Advocate Organization. 2. Appointment of Advocates is carried out by the Advocate Organization. A copy of the decision letter on the appointment of Advocates as referred to in paragraph (2) shall be submitted to the Supreme Court and the Minister.
} 
education, training and experience.

b) The existence of very high rules and moral standards. This is usually every professional actor basing his activities on the professional code of ethics

c) Serving the interests of the community, meaning that every profession must put personal interests under the interests of the community.

d) There is a special permit to run a profession. Each profession will always be related to the interests of the community, where human values are in the form of safety, security, survival and so on, so that to carry out a profession there must be a special permit.

e) Professionals are usually members of a profession.

These characteristics also characterize the journalist profession which is technically regulated in a journalistic code of ethics in accordance with the mandate of Article 7 paragraph (2) of the Press Law. Setting the journalistic code of ethics only emphasizes the duties and responsibilities of journalists in writing news without being accompanied by an appointment arrangement that is the standard of the journalist's profession. Journalist is a profession. He must have special skills (skills), extensive knowledge in his field (knowledge), and attitude (attitude) in accordance with the code of ethics or ethics (ethics) that applies, namely the journalistic code of ethics. Journalists are professionals, as are doctors, midwives, teachers, or lawyers who have a code of ethics.

The lack of standardization of the journalist's profession in the law makes everyone able to become a journalist without any conditions. And it's too easy to become a journalist, this also makes it uncertain how many and certainly not easy to monitor its performance. With weak qualifications accompanied by weak supervision there are problems related to the quality of journalists, including a weak understanding of journalistic ethics. As a result, unprofessional journalists emerged, which caused a detrimental attitude to press freedom because it gave rise to antipathy and unappreciated attitudes from the community towards this profession.

\section{CONCLUSION}

Based on the press coverage regulation that respects the presumption of innocence in the Press Law, the Press Council Regulation on Journalist Competence, and the freedom of press companies to regulate the professional standards of journalists should not conflict with the regulation of press coverage in national law. Through the press reporting system, the competence of legal journalists and journalist professional standards must be in the same arrangement in order to create harmony (harmony, compatibility, harmony) in order to prioritize legal certainty, so that it can shift wider interests. If legal certainty is followed absolutely, then the law will be useful for the law itself, and also for the community.

\section{REFERENCES}

Chairul Huda, The Meaning of the Principles of Presumption Not Guilty and Their Use in Press Practices, Jurnal Dewan Pers, edition No. 2, November 2010, page 38, accessed from https://dewanpers.or.id, on 8 May 2019.

Hendrayana, Upholding Press Freedom and the Implementation of the Presumption of Innocence Principle, Jurnal Dewan Pers, edition No. 2, November 2010, p. 84, accessed from https://dewanpers.or.id, on 8 May 2019.

Jealson, the Responsibility of Professional Journalists in the News, was accessed from https://steemit.com/jurnalis/@jealson, on 20 May 2019.

Romeltea, Professional standars of journalists, diakses dari https://romeltea.com/, Accessed on 10 May 2019. , Journalistic code of ethics: professional ethics of journalists, diakses dari https://romeltea.com, pada tanggal 19 Mei 2019.

Slamet Hariyadi, 2012, Disharmoni of Legal Products, in Sidharta et al, Towards the harmonization of the legal system as the Pillar of Management of the Indonesian Coastal Areas, Jakarta: Bapenas, accessed from https://www.academia.edu, on 15 May 2019.

Wina Armada, 1989, Face of Criminal Law Press. Jakarta: Pustaka Kartini. 2010, Avoid the accusation of violating the presumption of innocence, (online), (https://dewanpers.or.id), Accessed on 19 Februari 2019.

Law No. 40 of 1999 on Press

Law No. 18 of 2003 on Advocate

Law No. 12 Of 2011 on The Formation of Laws and Regulations.

Press Council Regulation No. 01 / Regulation-DP / X / 2018 on Journalist competency standars

Press Council Decree Number: 03 / SK-DP / III / 2006 concerning the Journalistic Code of Ethics, which means balanced is to provide space or time for reporting to each party proportionally. 